\title{
Ultimate Molecular Theory of Bitter Taste
}

\author{
Huazhong He, Ph. D \\ Molecular Recognition Organization, Elwood Rd., Delmar, NY 12054 \\ huazhong.he@gmail.com
}

\begin{abstract}
:
More than thirty years ago, I proposed a theory about sweet and bitter molecules' recognition by protein helical structures. Unfortunately the papers could not go to public platform until now. Inspired by the sweet taste theory ${ }^{1,2}$, this bitter taste theory conveys that bitter molecules are recognized by receptor protein helical structures. The recognition process is a dynamic action, in which the receptor protein helices have a torsion-spring-like oscillation between helical structures of 3.6 and 4 amino acids per turn. Based on the characteristics of the bitter receptor protein helix oscillation, it perfectly explains why in bitter molecules, only one unit of hydrogen donor $(\mathrm{DH})$ or hydrogen acceptor $(\mathrm{B})$ is enough in helping molecules to elicit bitter taste. The potential DH and $\mathrm{B}$ in bitter receptor are any $\mathrm{NH}$ or $\mathrm{O}$ of receptor's peptide $\mathrm{NHs}$ and $\mathrm{Os}$, which are the ones forming intramolecular $\mathrm{H}$-bonds responsible for the formation of receptor protein helical structures. Furthermore, only one unit of $\mathrm{DH}$ or $\mathrm{B}$ is allowed for structurally simple ligands. As recognition sites are only associated with a small fraction helix structure of whole bitter receptor, multiple binding sites or multiple receptors are well expected. As the oscillation may have different extent, it translates to bitterness intensity. According to ligand-receptor binding motion, bitter receptor could be divided into two kinds of spaces, which are similar to the situation in sweet taste receptor: main and side grooves. These have been discussed in context and especially great details in paper titled deciphering aspartyl peptide sweeteners ${ }^{2}$.
\end{abstract}

KEY WORDS: Bitter Receptor, Protein Helix, Helix Relaxing-Comeback TorsionSpring-Like Oscillation, DH Or B, Multiple Binding Sites, Potency Versus Intensity 


\section{INTRODUCTION}

Bitterness is a perception producing unpleasant taste, and one of the socalled five basic tastes (sweet, bitter, sour, salt, and umami) ${ }^{3,4}$. Similar to sweet taste molecules, bitter taste molecules have a large variety of different chemical structures, such as L-amino acids, peptides, amines, terpenoids, alkaloids, carbohydrates etc. When I was young, when taking bitter herbal medicine, my mother always added some sugar to the liquid to suppress the bitterness. The sweet and bitter tastes seem to be an opposite counterpart to each other psychologically and chemical structurally. In amino acids series, in general, Damino acids are sweet and L-amino acids are bitter. It is however that the observation is not really always true. D- and L- glucose, arabinose, xylose, and others have the same sweet taste and the similar sweetness power. ${ }^{5}$ It seems that asymmetric centers have no effect on the ability of a sugar to elicit sweet taste. Kubota and Kubo, ${ }^{6}$ referenced to Shallenberger and Acree's AH-B theory about sweet taste, proposed that bitter tastants need intramolecular hydrogen bond after studied the bitter molecules of Isodon. Lehmunn ${ }^{7}$ suggested the possible existence of sweet and bitter taste receptors with enantiomeric active sites. Belitz and Wieser noticed that unlike in sweet-tasting molecules, in bitter compounds, one polar group (electrophilic or nucleophilic), and a hydrophobic group $^{8}$ are required ${ }^{9}$. Now it is known that bitter tastants are recognized by Gprotein coupled receptors T2Rs ${ }^{10-12}$ and sweet tastants by T1R2/T1R3 ${ }^{13,14-19}$.

In the sweet taste phenomenon, mounting evidences have pointed that sweet molecules are recognized through the sweet receptor protein helix oscillation between 3.6 and 3 amino acids per turn ${ }^{1,2}$. This means sweet molecules tighten up the helix a little bit and then allow the tightened helix coming back to its original status. Through this kind of dynamic process of tightening and coming back, sweet molecules initiate sweet taste elicitation procedure. Inspired by this molecular theory about sweet taste ${ }^{1,2}$ and bitter taste structure activity relationship (SAR) in structurally various categories, this author is proposing a bitter taste molecular theory in which bitter molecules act through bitter receptor protein helix torsion-spring-like oscillation between 3.6 and 4 amino acids per turn. Current paper and the papers ${ }^{1,2}$ dealing sweet taste theory are independent. It is however that the combined information makes both of the sweet and bitter theories' foundation stronger. Following, the bitter theory will be described in the RESULTS section, then in DISCUSSION section, bitter tastestructure relationships and other aspects will be discussed in details.

\section{METHODS}

Where does the theory come from?

More than thirty years ago, upon the study of sweet/bitter-structure relationship with different structural characteristics, the theories were formed by the combined information. Through decades' efforts, the total three papers submitted at the same time basically described the reversal procedure for me to form the theory. As peers effectively blocked the publication for more than thirty years through peer-review processes, this allows the theories successfully evolved to current versions in an integrated 
form from the early version titled as Molecular Theory of Sweet and Bitter Tastes (unpublished).

Models used: The molecular models ${ }^{20-22}$ used here are to express what the theory likes to present. In a simplified way to understand the models, you can simply treat the models as hand-drawing pictures to describe the theory. As the molecular recognition process is dynamic, the models should only be considered as a moment in the dynamic process.

\section{RESULTS}

This theory conveys that bitter molecules are recognized by receptor protein helical structure. Recognition of bitter molecules is a dynamic process, in which the receptor protein helixes have a torsion-spring-like oscillation movement between helical structures of 3.6 and 4 amino acids per turn. In this section, receptor helices' behavior, the side chains' movement and other details will be discussed.

First thing first, there is a need to build a bitter receptor protein helix model to visualize the receptor's behavior. As the bitter taste recognition process involves a loosening helix process, the space left for bitter molecules gets squeezed and becomes narrowed. In the process of building sweet receptor model, L-leucine was used and provided a good model for the sweet taste theory's description. It is however that, as the helix with four amino acids per turn has a narrower groove than that with three amino acids per turn, if leucine is still used in building the bitter receptor model, basically the side chain of leucine is too big and it is very difficult to load bitter molecules to the bitter receptor model. The side chain size of L- $\alpha$-aminobutanoic acid is in the middle of actual natural occurring amino acids; the side chain characteristics of L- $\alpha$-aminobutanoic acid is relatively simple and avoids possible complication caused by selecting other much simpler or more complicated side chains for the current discussion. This model using L-a-aminobutanoic acid can satisfy basically all of the property needed to explain the recognition process for bitter molecules and will be used through out this paper.

\section{Bitter receptor protein helices' motion in the recognition process}

In Figure 1, molecular model is built ${ }^{20,21,22}$ to demonstrate bitter receptor protein helix torsion-spring-like oscillation. The left two diagrams are the molecular stick views and the right two diagrams are the molecular surface views of the helices of 3.6 and 4 amino acids per turn. Top diagrams (Phase I) show the original status of the bitter receptor protein helix; and lower diagrams (Phase II) show the final status of the bitter receptor protein helix. Top and lower diagrams show the statuses of helices of 3.6 and 4 amino acids per turn respectively. The bitter molecule recognition process is a dynamic oscillation process between these two phases. This oscillation process initiates the bitter taste elicitation procedure. 


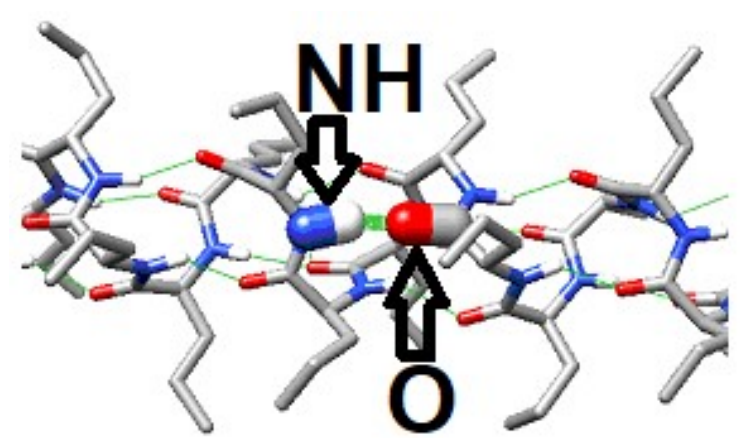

Stick View

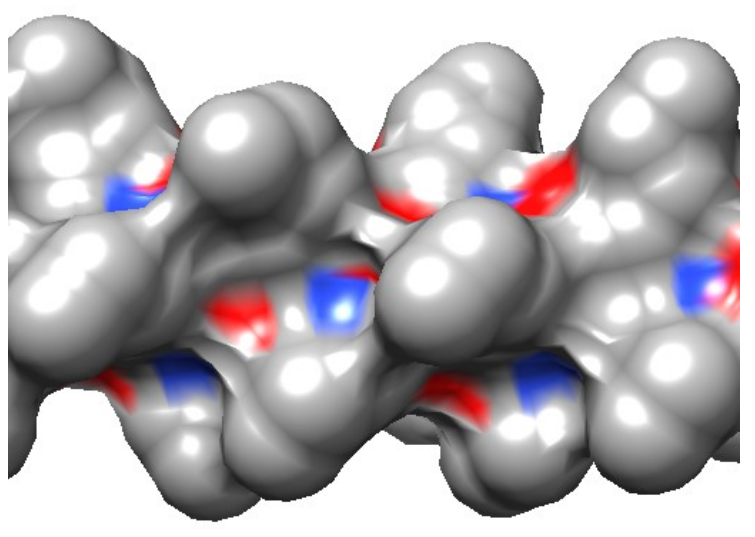

Surface View

Phase I (Original Status, 3.6 amino acids per turn)

torsion-spring-like oscillation moving forward to Phase II

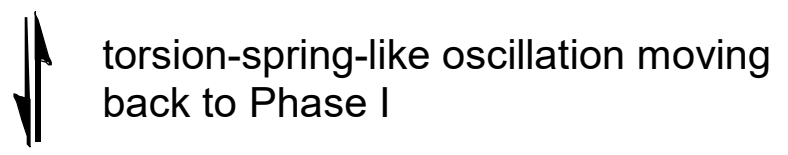

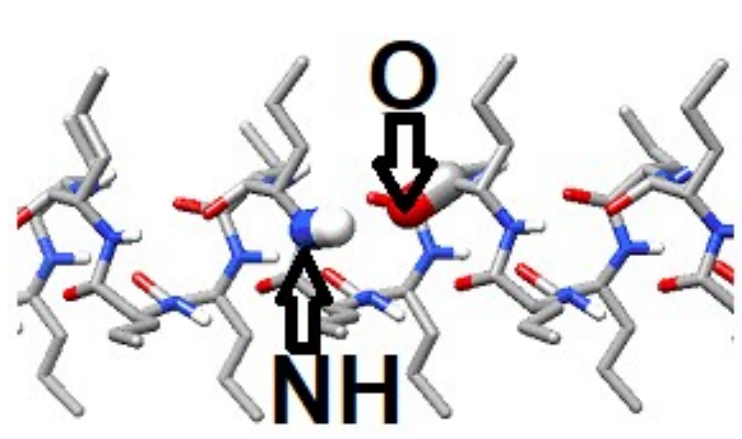

Stick View

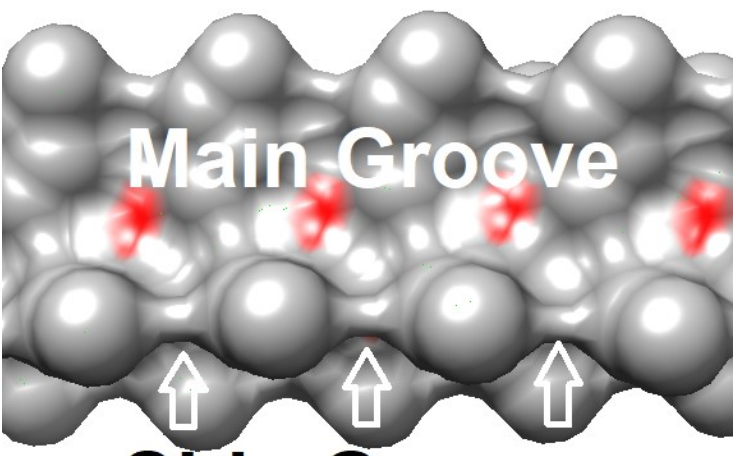

Side Grooves

Phase II (Final Status, 4 amino acids per turn)

Figure 1: Bitter receptor protein helix torsion-spring-like oscillation during the process of bitter molecules' recognition. (These bitter receptor helical models are built up using L-a-aminobutanoic acid). $\mathrm{NH}$ and $\mathrm{O}$ are highlighted and grooves are pointed out.

\section{Bitter Receptor Grooves}

The surface view can easily provide the grooves' views. The groove names are labeled in Phase II surface view of Figure 1. The corresponding spaces in Phase I are not easy to be pointed out directly in the diagram and can be established through the movement comparing the names labeled in Phase II. The spaces along the helix axis are called main grooves; the spaces between side chains in one turn away are named side grooves which are almost 
perpendicular to the main grooves, which are similar to the situation appeared in sweet taste receptor. These two grooves have different properties in holding bitter molecules due to the space size and motion during molecular recognition process. It is therefore the naming for the two grooves is also for the convenience of bitter-structure relationship discussion, which is very similar to the scenarios in sweet taste theory discussion. ${ }^{1,2}$

\section{Bitter Receptor Hydrogen Donor And Hydrogen Acceptor DH-B}

In the progress of searching for sweet taste theory, Shallenberger and Acree's AH-B theory about sweet taste was well cited. For bitter taste theory, this kind of concept was also adopted by some researchers. In the submission process of my manuscripts in the time period of more than three decades, I also attempted to recycle this term and give it a new meaning, only adverse end consequences came out however unfortunately. As their definition for AH-B is very different from the counterpart of my sweet taste theory, hydrogen donor $\mathrm{DH}$ and hydrogen acceptor B (DH-B) were adopted in my new versions of sweet taste theory ${ }^{1,2}$. In the sweet taste theory ${ }^{1,2}$, it has been well elucidated that there are two types of hydrogen donor and hydrogen acceptor DH-B moieties for both receptor and sweet molecules, which is very different from the old understanding. For the receptor, its $\mathrm{DH}-\mathrm{Bs}$ are receptor protein peptide bonds' $\mathrm{NH}-\mathrm{Os}$. . Inspired by my sweet taste theory, hydrogen donor $\mathrm{DH}$ and hydrogen acceptor $\mathrm{B}$ for bitter receptor also could be receptor peptide $\mathrm{NH}-\mathrm{Os}$. In sweet taste receptor, paired $\mathrm{NH}-\mathrm{O}$, which formed intramolecular $\mathrm{H}$ bond in the helix in phase I, could serve as a potential receptor $\mathrm{NH}-\mathrm{O}$. We can start from this to discuss the bitter receptor $\mathrm{NH}-\mathrm{Os}$ ' behavior and bitter tastants' $\mathrm{DH}-\mathrm{Bs}$ implication.

In the stick view of Figure 1, the peptide bond NHs and Os can be spotted. These $\mathrm{NHs}$ and $\mathrm{Os}$ are potential receptor hydrogen donor $\mathrm{DHs}$ and hydrogen acceptor Bs. From now on, receptor hydrogen donor $\mathrm{NHs}$ and hydrogen acceptor Os will be used to refer to receptor hydrogen donor $\mathrm{DHs}$ and hydrogen acceptor Bs. To perturb the helix, one efficient way to do that is to act on the helix-driving force the intramolecular hydrogen-bond through complementary $\mathrm{H}$-bond with ligands' $\mathrm{DH} / \mathrm{B}$. One pair of the peptide bond $\mathrm{NH}$ and $\mathrm{O}$ is highlighted, which has an intramolecular $\mathrm{H}$-bond. In sweet taste receptor, it would interact with nonintramolecular ligands' DH-B. We just imagine that bitter ligand also interacts in this way tentatively. From stick views of Figure 1, when the oscillation proceeds from phase I to phase II, the paired $\mathrm{NH}$ and $\mathrm{O}$ have a zigzag-type movement. While the paired $\mathrm{NH}$ and $\mathrm{O}$ move to phase II, it can be seen that the $\mathrm{NH}$ and $\mathrm{O}$ are moved to different main grooves. When the $\mathrm{NH}$ and $\mathrm{O}$ are in different main grooves, it is unlikely for both of the bitter tastants' DH and B to continuously binding with receptor's $\mathrm{O}$ and $\mathrm{NH}$ at the same time all the way through the oscillation process. This suggests that it is unlikely that for any kind of bitter molecules' both $\mathrm{DH}$ and $\mathrm{B}$ to act on the paired intramolecular $\mathrm{H}$ bond $\mathrm{NH}-\mathrm{O}$ s without being interrupted after the oscillation reaches phase II in general. This means that there is only one unit of $\mathrm{DH}$ or $\mathrm{B}$ is allowed for bitter tastants for simple molecules. This observation perfectly explains Belitz and Wieser ${ }^{9}$ noticed phenomenon that only one polar group is required for molecules' bitter taste. 
Having the bitter receptor information, bitterness potency, intensity, multiple receptor issues can be discussed.

\section{DISCUSSION}

Structure-bitter taste relationships are important measurements to validate this bitter theory. let's start with amino acids, amines, strychnine and its derivatives, denatonium and its derivatives, and other series of bitter compounds.

\section{Bitter Taste of L-Amino Acids}

In general, D-amino acids have sweet taste and L-amino acids bitter. To analyze the bitterness-structure relationship using this bitter taste theory, the oscillation process diagrams are shown in Figure 2. Here L-phenylalanine is used as an example. Upon the ligand approaching to the receptor, the ligand Lphenylalanine lets the helix moves to phase II (right) from phase I (left). The stick view, surface view and the combination are given out to show the needed details. As carboxylic and amino groups could be chosen as possible DH or B in helping the oscillation process. As discussed in the RESULTS section, there is only one unit is allowed. Which one to choose is the first issue needs to be solved.

First let's assume that the carboxylic group serves as ligands' B. Then corresponding carboxylic acids of amino acids should be bitter. It is however that this is not the case. For example, iso-caproic acid, caproic acid, n-valeric acid, iso-valeric acid, 3-Phenylpropionic acid, 3-(4-Hydroxyphenyl)propanoic acid, which are the corresponding acids of the amino acids listed in Table 1, do not have bitter taste. ${ }^{23} 2425$ After the possibility for carboxylic group serving as ligands' $B$ is excluded, the one left is the amino group serving as ligands' $\mathrm{DH}$. It is therefore that the bitter taste of L-amino acids should be close to that of their corresponding amines, and different from that of their carboxylic acids. As receptor grooves are shallow, it is expected that hydrophobic property would increase the bitterness potency, which is similar to sweet taste situation in general. As carboxylic group is hydrophilic, it should be expected that the corresponding amines should have higher potency or lower bitterness threshold than their amino acids. Table 1 lists bitterness threshold of both L-amino acids and their corresponding amines. The left set of compounds is about L-amino acids and the right set of compounds is about their corresponding amines. Each row shows their corresponding pairs. From these data presented, the threshold value for every left entry has a higher number than the right entry. These results well match the analysis drawn above. 

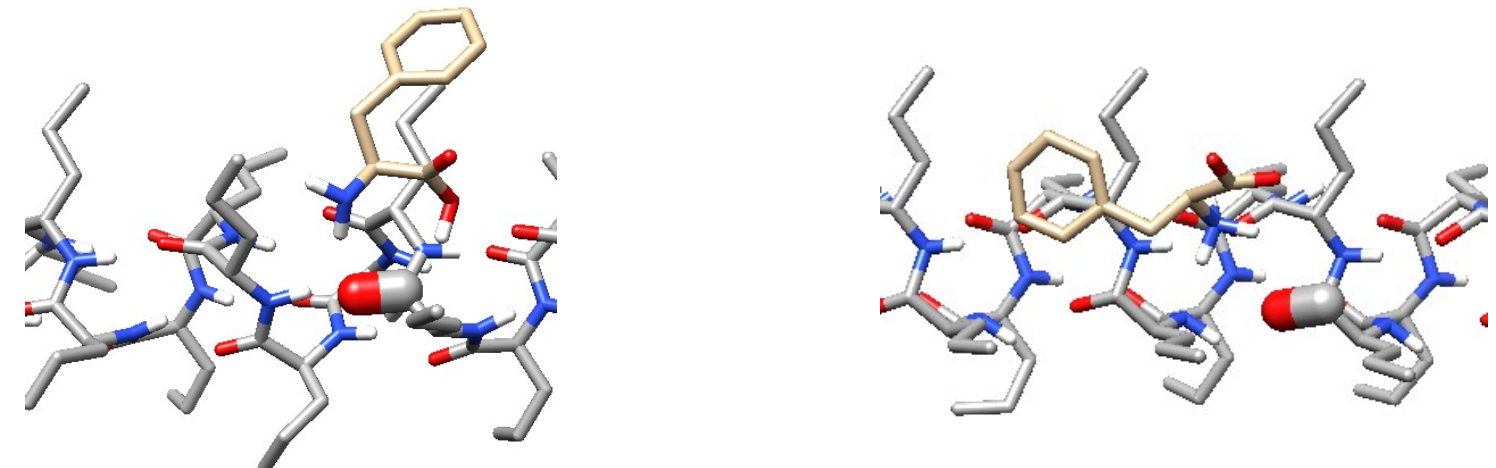

Molecular Stick View
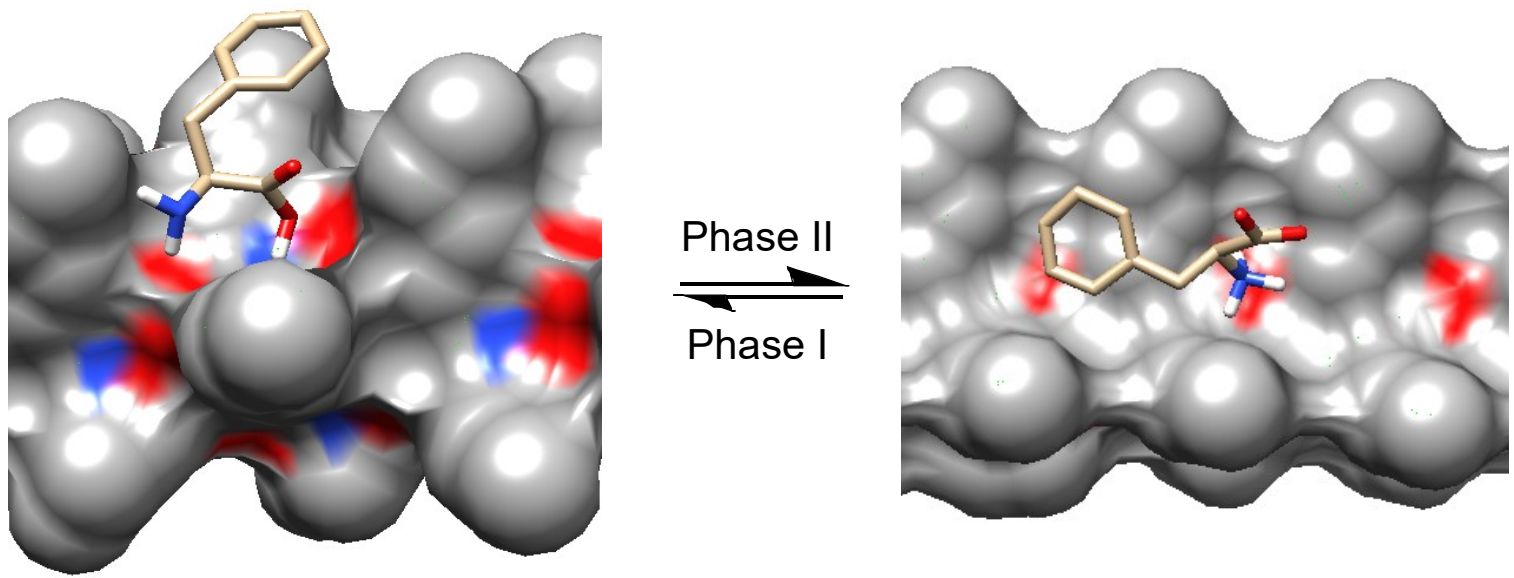

Receptor molecular surface view and ligand molecular stick view
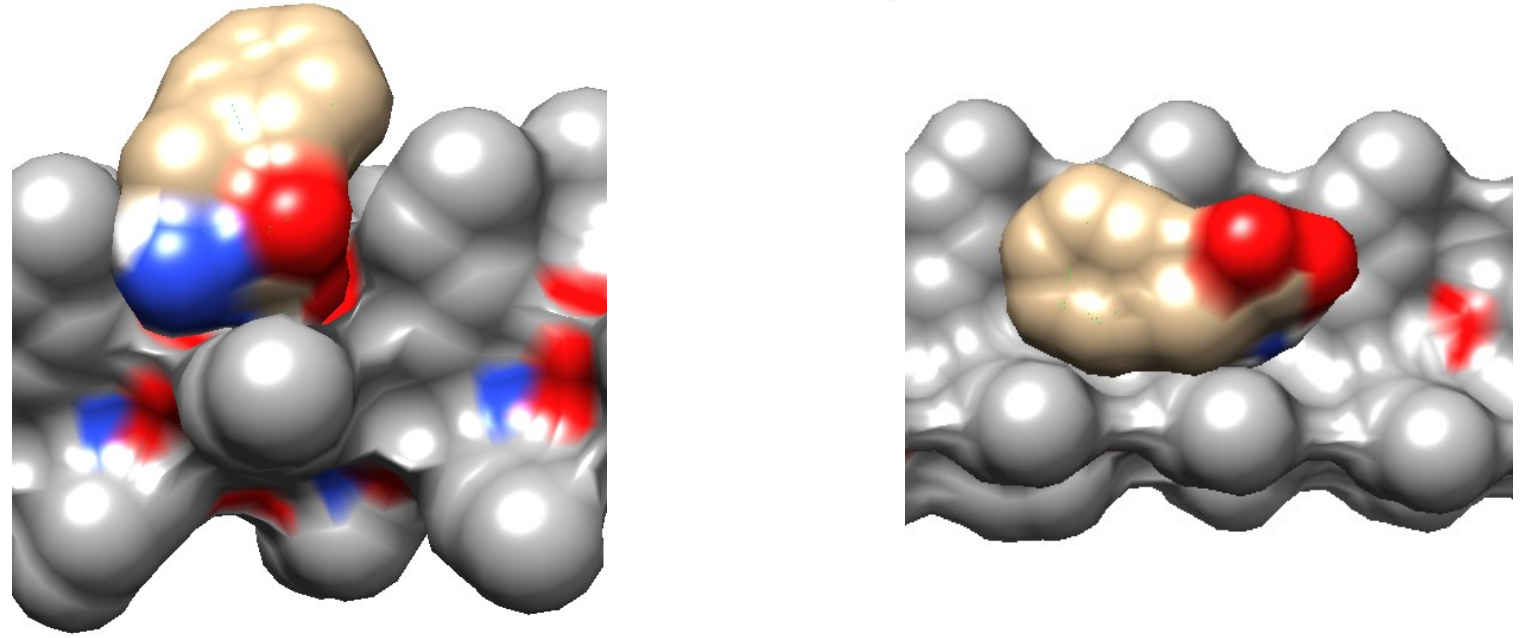

Phase I: Receptor Original Status with Ligand

\section{Molecular surface view}

Phase II: Receptor Final Status with Ligand

Figure 2: Torsion-spring-like oscillation of bitter receptor protein helixes with bitter molecule L-Phenylalanine in stick and surface views 


$\begin{aligned} & \text { Table } 1 \text { Bitterness Threshold Comparison of L-amino acids and their } \\ & \text { corresponding amines } \\ & \text { No. }\end{aligned}$ Compounds $^{C_{\text {tbi }}(\mathbf{m M})}$ No. Compounds
$\mathrm{C}_{\text {tbi }}$ (mM)

No.: Numbering of compounds; $\mathrm{C}_{\mathrm{tbi}}$ : bitterness recognition threshold.

According to the bitter theory, there is only one unit of ligands' DH or B can serve as a helper for the receptor protein helix oscillation and eventually for the bitter taste for simple molecules. Even if both potential DH and B exist in one molecule, only one unit can serve as a helper and another one just serve as a regular substitute. In amino acid series, carboxylic group here happens to be an adverse hydrophilic group and provided higher bitterness threshold for amino acids comparing to their corresponding amines. This series is a perfect example about one and only one unit is allowed about $\mathrm{DH}$ or $\mathrm{B}$ according to this bitter taste theory. Carboxylic group can also serve as bitter ligands' B in helping bitter elicitation oscillation and give carboxylic acids bitter taste. It is however that the ability to elicit bitter taste seems not as powerful as their corresponding amines. Table 2 shows some bitter and non-bitter long chain aliphatic acids. So carboxylic group still have the capability to serve as ligands' B. This may be why a lot of 
natural amines have very low bitterness threshold. Now let's look into one of the most bitter amine compound strychnine.

Table 2 Bitter Taste of Aliphatic acids

\begin{tabular}{|c|c|c|c|c|}
\hline \multirow[b]{2}{*}{ No. } & \multirow[b]{2}{*}{$\begin{array}{l}\text { Compound } \\
\text { Name }\end{array}$} & \multirow[b]{2}{*}{ Compound Structure } & \multicolumn{2}{|c|}{$\mathrm{C}_{\mathrm{tbi}}(\mathrm{mM})$} \\
\hline & & & $\begin{array}{c}\text { Wieser et } \\
\left.a\right|^{27}\end{array}$ & $\begin{array}{l}\text { Lainer e } \\
\qquad l^{28}\end{array}$ \\
\hline 13 & Palmitic acid & & NA & 0.81 \\
\hline 14 & Stearic acid & & n. bi. (22) & 0.81 \\
\hline 15 & Oleic acid & & $9-12$ & 0.98 \\
\hline 16 & $\begin{array}{c}\text { 9t-Octadecenoic } \\
\text { acid }\end{array}$ & & n. bi. (22) & NA \\
\hline 17 & Linoleic acid & & $4-6$ & 0.93 \\
\hline 18 & $\begin{array}{l}\text { a-Linolenic acid } \\
\text { VA: not available; }\end{array}$ & & $0.6-1.2$ & 0.28 \\
\hline
\end{tabular}

\section{Bitter Taste of Strychnine and Its Derivatives}

Strychnine (19) is a very toxic compound. ${ }^{29}$ Its oral $L_{50}$ in dogs, cattle, horses, and pigs is $0.5-1 \mathrm{mg} / \mathrm{kg}$, and in cats is $2 \mathrm{mg} / \mathrm{kg}$. Strychnine (19) is a very bitter compound (bitterness threshold: 1:130,000 (Merck Index, 1989)). Its dihydro compound (22) has a bitter taste similar to that of strychnine (19). ${ }^{30}$ Its dimethoxy compound brucine (21) has a lower bitterness threshold: 1:220,000 (Merck Index, 1989). A very interesting compound pseudostrychnine (20), which has a hydroxyl group at the $\alpha$-carbon of the free amine's nitrogen, has no bitter taste. ${ }^{31}$ The pKa values of pseudostrychnine $(\mathbf{2 0})$ and strychnine (19) are 5.50 and 7.37 respectively. ${ }^{32}, 33$ This suggests that at physiological $\mathrm{pH}$, the tertiary amine nitrogen of pseudostrychnine $(\mathbf{2 0})$ can not be protonated and no $\mathrm{NH}^{+}$is formed. If the $\mathrm{OH}$ group does not interfere the capability for possible $\mathrm{NH}^{+}$to serve as $\mathrm{DH}$, pseudostrychnine (20) should have bitter taste at around $\mathrm{pH} 5.5$ or lower. If pseudostrychnine $(\mathbf{2 0})$ would be still not bitter at $\mathrm{pH} 5.5$ or lower, that still would be an interesting piece of information, because it could mean that the hydroxyl group is interfering with the binding/oscillation process. In Human Bitter Taste Receptor hTAS2R46 assay, strychnine (19) and strychnine-N-oxide (23) show thresholds at 0.1 and $30 \mu \mathrm{M}$ respectively. The difference is 300 times. This also tells that one atom change makes a big impact. Only reliable explanation for this is that the capability to form ligand $\mathrm{DH}$ (protonated tertiary amine $\mathrm{NH}^{+}$) in strychnine (19) completely disappeared in strychnine-N-oxide (23); the binding mode of strychnine-N-oxide (23) is different from that of strychnine (19) and makes it have a very different bitterness potency. This is another series of example about ligand's DH. Now let's move on to grooves for their impacts on bitterness potency. 


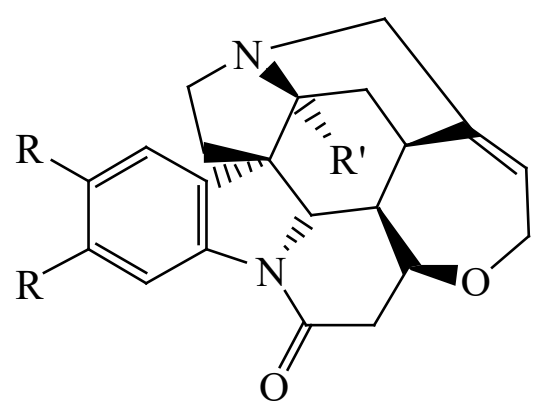

19) $\mathrm{R}=\mathrm{H}, \quad \mathrm{R}^{\prime}=\mathrm{H}$ : $\quad$ Strychnine

20) $\mathrm{R}=\mathrm{H}, \quad \mathrm{R}^{\prime}=\mathrm{OH}$ : $\quad$ Pseudostrychnine

21) $\mathrm{R}=\mathrm{CH}_{3} \mathrm{O}, \mathrm{R}^{\prime}=\mathrm{H}$ : $\quad$ Brucine<smiles>O=C1C[C@@H]2OCC[C@@H]3CN4CC[C@]56c7ccccc7N1[C@H]5[C@H]2[C@H]3C[C@H]46</smiles>

22) Dihydrostrychnine

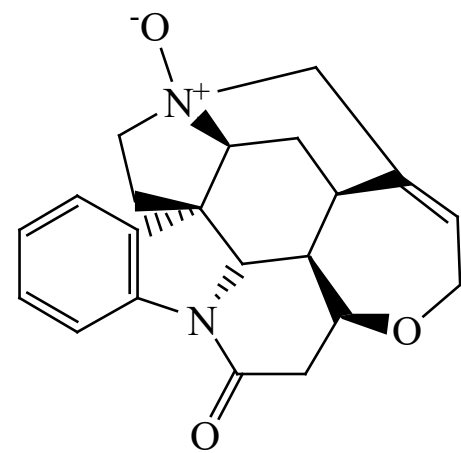

23) Strychnine N-Oxide

Figure 3 Structures of Strychnine and its derivatives

\section{Bitterness - Ring Size Relationship}

In the papers about sweet taste, ${ }^{1,2}$ there are many examples that could be used to address the groove issues. About bitter receptor protein helix grooves, there are less examples which could be used to deal with them systematically. In the limited data, Table 3 lists two sets of aspartyl peptide compounds. When the C-end ring size get larger, the taste of the peptide changes to bitter gradually, then becomes tasteless, although left side set of peptide is dipeptides and right side set of peptide is tripeptide. For sweeteners, the binding pattern is clear, the rings in different sets bind at relative different sites. With this helix recognition theory, it is very easy to understand the trend, because they act on main groove. Only difference is that they act on different relative spots. From compound $\mathbf{2 7}$ to $\mathbf{2 8}$, the taste from bitter to very bitter is due to the increase in hydrophobicity. Compound 29 turns to tasteless when one more $-\mathrm{CH}_{2}$ - group is added due to ring's contribution towards' binding/oscillation. It is worthy to remind that the groove for ligands to tackle receptor is very shallow. When a larger part of a molecule is not contributing to the binding/oscillation, the molecule may loss the ability to do that at all. This kind of trend will be able to see in cycloalkanones and 1-amino-cycloalkane-1-carboxylic acid series. 
Table 3 Ring size-sweetness relationship of L-aspartyl peptides L- aspartyl- $\alpha$-aminocycloalkanecarboxylic acid methyl esters<smiles>CCC(CC)(NC(=O)[C@H](N)CC(=O)O)C(=O)OC</smiles>

$\begin{array}{ccc}\text { No. } & \text { n } & \text { Taste } \\ \mathbf{2 4} & 3 & \text { Sweet } \\ \mathbf{2 5} & 4 & \text { Sweet } \\ \mathbf{2 6} & 5 & \text { Sweet } \\ \mathbf{2 7} & 6 & \text { Bitter } \\ \mathbf{2 8} & 7 & \text { Very Bitter } \\ \mathbf{2 9} & 8 & \text { TL }\end{array}$

TL: Tasteless.

L-Asp-D-Ala-AA-OCH<smiles>CCC(CC)(NC(=O)C(C)NC(=O)[C@@H](N)CC(=O)O)C(=O)OC</smiles>

No.

30

31

32

33

34

35
Taste

Sweet

Sweet

Sweet

Sweet

Bitter

Bitter

From compound $\mathbf{3 6}$ to $\mathbf{4 0}$, cycloalkanones increase their $-\mathrm{CH}_{2-}$, increase their hydrophobicity and eventually increase the bitterness potency. When reach to 43 , as mentioned before, the ring size becomes too big to contribute to the binding/oscillation. It is therefore that $\mathbf{4 3}$ is neutral. From compound $\mathbf{4 4}$ to $\mathbf{5 1}$, the sweet taste potency becomes higher (lower threshold) (44 to 46), then lower (47 to $\mathbf{4 8}$ ), then no more sweet taste (49 to 51 ); the bitter taste potency becomes higher (lower threshold) (45 to $\mathbf{4 8}$ ), then lower (49), then no more bitter taste (50 to 51); For the bitter taste, as cycloalkanones can only provide ligands' $B$ and amino-cycloalkane-1-carboxylic acids should only use their ligands' $\mathrm{DH}$ as discussed in amino acid and amine bitter taste series, their binding manners are different, but they show similar trend. This is because they act on receptor protein helix main grooves no matter dealing with sweeteners or bitter tastants. 
Table 4 Taste-Ring Size Relationships of Cycloalkanones ${ }^{9}$ and 1-aminocycloalkane-1-carboxylic acids ${ }^{37,38}$
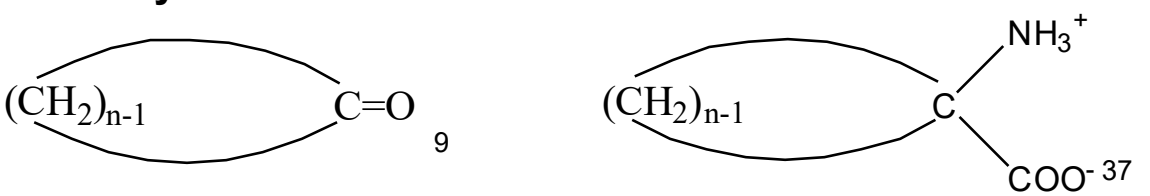

$\begin{array}{cccccc}\mathbf{n} & \text { No. } & \mathbf{C}_{\text {tbi }}(\mathbf{m M}) & \text { No. } & \mathbf{C}_{\text {tsw }}(\mathbf{m M}) & \mathbf{C}_{\text {tbi }}(\mathbf{m M}) \\ 4 & \mathbf{3 6} & \text { neutral } & \mathbf{4 4} & 20-30 & \text { NA } \\ 5 & \mathbf{3 7} & 10-15 & \mathbf{4 5} & 3-6 & 95-100 \\ 6 & \mathbf{3 8} & 6-10 & \mathbf{4 6} & 1-3 & 45-50 \\ 7 & \mathbf{3 9} & 5-6 & \mathbf{4 7} & 2-4 & 13-15 \\ 8 & \mathbf{4 0} & 2-4 & \mathbf{4 8} & 2-4 & 2-5 \\ 9 & \mathbf{4 1} & \mathrm{NA} & \mathbf{4 9} & \text { N.S. }(50)^{*} & 20-50 \\ 11 & \mathbf{4 2} & \mathrm{NA} & \mathbf{5 0} & \text { N.S. }(20)^{*} & \text { N.B. (20) } \\ 12 & \mathbf{4 3} & \text { neutral } & \mathbf{5 1} & \text { N.S. }(20)^{*} & \text { N.B. (20) } \\ : \text { sweetness recognition threshold; NA: not available; N.S.: not sweet; N.B.: } \\ \text { bitter, in parenthesis maximum concentration tested. }\end{array}$

It is the helix recognition theory makes the comparison possible for the trend of sweet versus bitter compounds; and compounds with hydrogen donor DH type versus hydrogen acceptor B type. Next let's see more examples about main groove, and also side groove in denatonium series compounds.

\section{Bitter Taste of Denatonium and Its Derivatives}

Now many examples have been provided to deal with main grooves. What is the side groove's contribution in bitterness elicitation? In the aspartyl peptide sweetener series, ${ }^{2}$ there are many examples discussed. As there is not many bitter compounds can deal with the information, we are going to only briefly discuss about side grooves. For more in-depth details, intermolecular weak interactions and side groove sections in aspartyl sweeteners paper ${ }^{2}$ should be read. Luckily enough, Saroli's four papers ${ }^{39,40,41,42}$ about denatonium derivatives have showed some information about this issue.<smiles>CC[N+](CC)(CC(=O)Nc1c(C)cccc1C)Cc1ccccc1</smiles>

Denatonium salts have been used as aversive agent, which are not known to pose any long-term health risks; its $\mathrm{LD}_{50} \mathrm{~s}$ for various species range from 500 to $1400 \mathrm{mg} / \mathrm{kg} .{ }^{43}$ Denatonium salts are one of the most bitter compounds. Saroli synthesized and found out the bitterness thresholds about dozens of compounds which structures are related or close to denatonium salts (some just dipeptides or amino acid amide). The contents are briefly summarized as: the bitterness for the 
compounds basically are guaranteed, which means there is no critical atom or group identified for the bitter taste: the length for the compounds basically have some flexibility; having or not having the amide part is not important; halide or benzoate basically having the same threshold; hydrophobility provided higher activity (lower threshold); both ends with a benzene ring would provide higher activity.

For the sweetness-structure relationship of Aspatyl peptide stweeteners, the aspartyl part is basically an essential structure and retained through most of sweetener exploration, although other parts could have very flexible variation. The reason has been discussed in the paper titled deciphering aspartyl peptide sweeteners ${ }^{2}$ that in aspartyl structure there is critical hidden information $\mathrm{H}$ bonding-like DH-B moiety. From Saroli's research on bitter-structure relationship of denatonium analogues, it was found that, the bitterness almost exist in all the cases no matter how fundamental changes on both sides, chain length, etc. In bitter molecules, there is no such crucial factor as subtle DH-B-like moiety in helping bitter receptor protein helix oscillation.

\section{Table 5 Sweetness-Structure Relationship of N-Substitute Aspartame and Bitterness-Structure Relationship of Denatonium Analogues}

\begin{tabular}{|c|c|c|c|c|}
\hline \multirow[b]{2}{*}{$\mathbf{R}$} & \multirow[b]{2}{*}{ No. } & \multirow{2}{*}{ Sweetness * ${ }^{44}$} & \multicolumn{2}{|c|}{$\begin{array}{c}\mathrm{H}_{3} \mathrm{C} \\
\mathrm{Cl}^{-} \mathrm{C}_{-}^{-} \mathrm{N}^{+} \mathrm{CH}_{2} \mathrm{CONH} \\
\mathrm{H}_{3} \mathrm{C}^{\prime}\end{array}$} \\
\hline & & & No. & $\mathrm{C}_{\mathrm{tbi}}(\mathrm{M})^{39}$ \\
\hline $\mathrm{C}_{5} \mathrm{H}_{11}$ & NA & NA & 55 & $2-4 \times 10^{-5}$ \\
\hline $\mathrm{C}_{6} \mathrm{H}_{13}$ & NA & NA & 56 & $4-8 \times 10^{-5}$ \\
\hline $\mathrm{C}_{8} \mathrm{H}_{17}$ & NA & NA & 57 & $4-8 \times 10^{-5}$ \\
\hline $\mathrm{C}_{10} \mathrm{H}_{21}$ & NA & NA & 58 & $4-8 \times 10^{-5}$ \\
\hline $\mathrm{C}_{6} \mathrm{H}_{5} \mathrm{CH}_{2}$ & NA & NA & 59 & $1-2 \times 10^{-7}$ \\
\hline $\mathrm{C}_{6} \mathrm{H}_{5} \mathrm{CH}_{2} \mathrm{CH}_{2}$ & 52 & Faintly SWEET & 60 & $2-4 \times 10^{-5}$ \\
\hline $\mathrm{C}_{6} \mathrm{H}_{11} \mathrm{CH}_{2} \mathrm{CH}_{2} \mathrm{CH}_{2}$ & 53 & 0 & NA & NA \\
\hline $\mathrm{C}_{6} \mathrm{H}_{5} \mathrm{CH}_{2} \mathrm{CH}_{2} \mathrm{CH}_{2}$ & 54 & 1000 & 61 & $2-4 \times 10^{-5}$ \\
\hline
\end{tabular}

For sweet taste of N-R-Aspartame (Table 5), structurally close counterparts of $\mathbf{5 4}\left(\mathrm{R}=\mathrm{C}_{6} \mathrm{H}_{5} \mathrm{CH}_{2} \mathrm{CH}_{2} \mathrm{CH}_{2}\right)$ have much less sweetness potency: $\mathbf{5 3}$ $\left(\mathrm{R}=\mathrm{C}_{6} \mathrm{H}_{11} \mathrm{CH}_{2} \mathrm{CH}_{2} \mathrm{CH}_{2}, 0\right), 52\left(\mathrm{R}=\mathrm{C}_{6} \mathrm{H}_{5} \mathrm{CH}_{2} \mathrm{CH}_{2}\right.$, faintly sweet). Compound $\mathbf{5 3}$ does not have flat ring, the cyclohexyl group can not insert into the side groove of sweet receptor protein; and $\mathbf{5 2}$, the bridge $\left(\mathrm{CH}_{2} \mathrm{CH}_{2}\right)$ is too short, the phenyl ring can not or can not fully reach the side groove. Due to the difference in binding pattern or inability in binding, $\mathbf{5 4}$ has a much better sweetness potency than $\mathbf{5 2}$ and 53. The importance for the phenyl ring here is that the side chains of side groove have a movement like sliding on the phenyl ring. Non-plane structure of cyclohexyl group can not serve the purpose.

For bitter taste in denatonium analogue series (Table 5), Compound 59 $\left(\mathrm{R}=\mathrm{C}_{6} \mathrm{H}_{5} \mathrm{CH}_{2}\right)$ has a much higher potency $(>100$ times) than its close 
counterparts $(\mathbf{5 5}-\mathbf{5 8}, \mathbf{6 0}, \mathbf{6 1})$. For compounds $\mathbf{5 5}-\mathbf{5 8}\left(\mathrm{R}=\mathrm{C}_{5} \mathrm{H}_{11}, \mathrm{C}_{6} \mathrm{H}_{13}, \mathrm{C}_{8} \mathrm{H}_{17}\right.$, $\mathrm{C}_{10} \mathrm{H}_{21}$ ), they do not have a flat phenyl ring. Their $\mathrm{R}$ groups can not insert into the side groove of bitter receptor protein. For compounds 60, 61, the bridges $\left(\mathrm{CH}_{2} \mathrm{CH}_{2}, \mathrm{CH}_{2} \mathrm{CH}_{2} \mathrm{CH}_{2}\right.$ respectively) are too long. Their phenyl ring can not optimally reach the side groove. This explains the difference about main grooves and side grooves in structural requirement and the enhancement effects for bitterness potency. Only with this helix recognition theory, it is possible to discuss sweet taste of aspartyl peptide and bitter taste of denatonium analogues side by side.

With Saroli's work, some SAR information about main grooves can also be discussed and compared with L-aspartyl peptide sweet SAR. In L-Asp-D-Ala$\mathrm{NHR}$ sweetener series, the $\mathrm{R}$ groups act on receptor main groove. When $\mathrm{R}=\mathrm{C}_{6} \mathrm{H}_{3}\left(2,6-\left(\mathrm{CH}_{3}\right)_{2}\right)(66)$, the sweetness activity is better than its corresponding phenyl ring (65) or open chain $63\left(\mathrm{R}=\mathrm{CH}_{2} \mathrm{CH}_{2} \mathrm{CH}_{3}\right)$ compounds. In denatonium derivatives series, they also have similar structure-bitterness relationship. When $\mathrm{R}=\mathrm{C}_{6} \mathrm{H}_{3}\left(2,6-\left(\mathrm{CH}_{3}\right)_{2}\right)(\mathbf{7 1})$, the bitterness activity is better (lower threshold) than its corresponding phenyl ring (70) or open chain $67\left(\mathrm{R}=\mathrm{CH}_{3}\right), 69\left(\mathrm{R}=\mathrm{CH}_{2} \mathrm{CH}\left(\mathrm{CH}_{3}\right)_{2}\right)$ compounds. In these cases, phenyl rings or open chains do not provide drastic change in sweetness/bitterness. Again, the sweet and bitter theories allow the structure - sweet/bitter taste relationship discussion side by side.

Table 6 Some SAR Similarity Between Sweet L-Asp-D-Ala Amide And Bitter Denatonium amide side.

\section{L-Asp peptides Denatonium Derivatives}

\author{
L-Asp-D-Ala- \\ $\mathrm{NHR}$
}

$\begin{array}{cc}\text { No. } & \mathbf{R} \\ \mathbf{6 2} & \mathrm{CH}_{3} \\ \mathbf{6 3} & \mathrm{CH}_{2} \mathrm{CH}_{2} \mathrm{CH}_{3} \\ \mathbf{6 4} & \mathrm{CH}_{2} \mathrm{CH}_{\left(\mathrm{CH}_{3}\right)_{2}} \\ \mathbf{6 5} & \mathrm{C}_{6} \mathrm{H}_{5} \\ \mathbf{6 6} & \mathrm{C}_{6} \mathrm{H}_{3}\left(2,6-\left(\mathrm{CH}_{3}\right)_{2}\right)\end{array}$

Sweetness* ${ }^{* 45}$

NA

72

NA

38

500<smiles>[R]NC(=O)C[N+](C)(C)Cc1ccc(Cl)cc1</smiles>

No.

67

68

69

70

71
$\mathrm{C}_{\text {tbi }}(\mathbf{M})^{\star *} 41$

$2-4 \times 10^{-5}$

$\mathrm{NA}$

$1-2 \times 10^{-6}$

$4-8 \times 10^{-6}$

$1-2 \times 10^{-7}$

\section{Bitterness Intensity}

In RESULTS section, the bitter theory has stated that the recognition process is an oscillation action of the bitter receptor protein helix. The oscillation process happens between the helices of 3.6 and 4 amino acids per turn. This oscillation is the key for the bitterness elicitation. A question could be raised out of this statement: does the interaction of bitter molecule with bitter receptor protein helix have the perfect oscillation as shown in Figure 1 in all the occasion? The answer, of cause, is negative. This would pop up another question: what does that mean then? This introduces a term called intensity. Different extent of 
the bitter receptor protein helix oscillation results in different bitterness intensity. Most reports deal with threshold or the like. Those are about the potency.

There are plenty of research dealt with bitterness intensity issues: for example, researches on iso- $\alpha$-acids' bitter intensity in different concentration ${ }^{46}$, tasters \& non-tasters' bitter intensity of caffeine and quinine at four concentration levels ${ }^{47}$, super-tasters, medium-tasters, non-tasters' bitter intensity of 6-npropylthiouracil (PROP) in different concentration ${ }^{48}$, phenylthiocarbamide (PTC) bitterness intensity to predicts TAS2R38 genotype ${ }^{49}$, and others. Different concentrations of a bitter compound acting on a receptor or different composing amino acids in receptors responding to a bitter compound will make the oscillation to a different extent, which translates to different bitterness intensity. Bitterness potency and intensity are two characteristics for bitter compounds. Now let's deal with bitter receptors.

\section{Bitter Receptors}

This whole theory is about bitter molecules recognized by helical structures of bitter receptors. This kind of helix relaxing-comeback torsion-springlike oscillation movement is like the pronunciation of word "bitter". No matter where you say it, as long as you can let the down stream hear it, it will be understood as "bitter". As a helix is only a small part of a receptor complete structure, multiple binding sites and/or multiple receptors are well expected from the beginning of the theory. Thirty years ago, peer challenged the existence of helical structure. At that time, there was no information about receptors. I do not think people in this area would still respect the challenge today. Bitter receptors are G-protein coupled receptors, which are seven trans-membrane helical structure proteins. Two research groups discovered bitter taste receptors in human and mouse in 2000. ${ }^{10-12}$ Bitter taste in humans is believed to be mediated by 25 receptors (hT2Rs, or TAS2Rs). ${ }^{50}$ Each receptor responds to certain bitter compounds: for example, hT2R38 for phenylthiocarbamide (PTC) and 6-npropylthiouracil (PROP), ${ }^{51,52} \mathrm{hT} 2 \mathrm{R} 61$ for 6-nitrosaccharin, hT2R44 for denatonium and 6-nitrosaccharin, ${ }^{53} \mathrm{hT} 2 \mathrm{R} 47$ for denatonium in micromolar concentration, hT2R7 for strychnine, quinacrine, chloroquine and papaverine ${ }^{54}$. In the bitter receptor oscillation process, the main groove is getting narrower. This may make the receptor more sensitive to bitter molecules' size, shape, and other properties, and need different receptors to sense different bitter molecules. The "bitter blindness" phenomenon, such as Phenylthiocarbamide (PTC)'s taster and non-taster issue,$^{55}$ may be also due to this same reason. In sweet molecules' recognition process, it has been known that different molecules could bind to different spots of sweet receptor (T1R2/T1R3). Could one receptor bind with bitter molecules at different spots? Very likely, if not absolutely, the answer is positive. 


\section{CONCLUSION}

More than thirty years ago, I proposed a theory about sweet and bitter molecules' recognition by protein helical structures. Unfortunately the papers could not go to public platform until now. Inspired by the sweet taste theory ${ }^{1,2}$, the bitter taste theory is also updated. The ideas for the formation of the sweet and bitter taste theories are basically came from the study of sweetness-structure relationships, although the bitterness-structure relationship played some roles too in the process. The reason is that the systematic researches on sweeteners are much more extended than those on bitter compounds. The processes for the theories' formation are basically reversal procedures for the information presented here and in other papers ${ }^{1,2}$. The total three papers are independent and as a whole make the foundation for the theories very strong.

In the very beginning of this paper, the bitter theory has described as that the bitter molecule recognition process is a torsion-spring-like oscillation action of the bitter receptor protein helix. The oscillation process happens between the helices of 3.6 and 4 amino acids per turn (helix relaxing-comeback torsionspring-like oscillation). This oscillation is the key for the bitterness elucidation. To help this kind of oscillation, receptor protein helix driving force H-bonds' $\mathrm{NH}$-Os are important points to be perturbed, which are called receptor's hydrogen donor and hydrogen acceptor NH-Os. The corresponding counterparts for bitter molecules are named as $\mathrm{DH}-\mathrm{Bs}$.

In sweet taste theory, it was found out that there are two types of $\mathrm{DH}$ $\mathrm{B} / \mathrm{NH}-\mathrm{O}$ entities for sweet compounds and receptor respectively, which play important role in sweetness elicitation. To look into the similar counterparts in bitter molecules and receptor, the receptor protein helix oscillation is carefully examined. From the observation of the helices' oscillation pattern, the intramolecular $\mathrm{H}$ bond paired hydrogen donor $\mathrm{NH}$ and hydrogen acceptor $\mathrm{O}$ in helix of 3.6 amino acids per turn locate at different main grooves after oscillation process is moved to helix of 4 amino acids per turn. This unprecedented finding suggests that only one unit of receptor $\mathrm{NH}$ or $\mathrm{O}$ is involved for the bitter molecules' action on the bitter receptor; and only one unit of DH or B is allowed for structurally simple molecules. In this way, based on the characteristics of the bitter receptor protein helix oscillation, it perfectly explains why in bitter molecules, only one unit of hydrogen donor $(\mathrm{DH})$ or hydrogen acceptor $(\mathrm{B})$ is enough in helping molecules to elicit bitter taste. The potential $\mathrm{DH}$ and $\mathrm{B}$ in bitter receptor are any $\mathrm{NH}$ and $\mathrm{O}$ of receptor's peptide $\mathrm{NHs}$ and $\mathrm{Os}$, which are the ones forming intramolecular $\mathrm{H}$-bonds responsible for the formation of receptor protein helical structures. In helping bitter taste elicitation, the hydrogen bonding interaction between one unit of $\mathrm{NH}$ or $\mathrm{O}$ of receptor and one unit of $\mathrm{B}$ or $\mathrm{DH}$ of bitter taste ligands is sufficient, which is very different from the sweet receptor/ligand $\mathrm{NH}-\mathrm{Os} / \mathrm{DH}-\mathrm{Bs}$ ' interactions which are more complicated. Experts in this area should treat this alone as an important contribution to bitter taste research area.

In the process of building a bitter receptor helix model, the size of amino acid side chain becomes an issue. As the helix of 4 amino acids per turn has a 
narrower width of main groove than that of helix of 3 amino acids per turn, Lleucine used in building sweet receptor model is too big for bitter receptor model building, which means that it is not easy to put bitter molecules into the grooves. It is therefore that the bitter receptor model is built using L-aminobutanoic acids.

According to ligand-receptor binding manner and motion, bitter receptor could be roughly divided into two kinds of spaces to accommodate bitter molecules: one is named here as main grooves which is the grooves following receptor protein carbon to nitrogen end helix axis (referring to the helix with 4 amino acids per turn in which it is easier to be identified); another is named as side grooves which are the grooves between side chains and almost perpendicular to the main grooves, which is similar to the situation appeared in sweet taste receptor. The contents discussed above basically lead to the explanation of bitterness potency.

From the discussion of the bitterness of L-amino acids, amines, strychnine derivatives, it demonstrated the importance of bitter molecules DH. From bitter tastes of carboxylic acids and cycolketones, it shows the function of bitter ligands' B. By comparing sweet/bitter taste trends of cyclo-compounds, it probed the main grooves, which not just the bitter receptor's main groove, but also sweet receptor' main grooves width. The groove impacts on sweet and bitter taste are similar, but not the same. Only through these theories about sweet and bitter taste, it is possible to have this kind of comparison side by side. Again, only with these theories about sweet and bitter taste, it becomes possible for the comparison about Denatonium derivatives' SAR similarities with L-aspartyl sweeteners. Bitter receptor's side groove issue is briefly gone through using denatonium derivatives' SAR information. As bitter compounds' SAR information is not as rich as that in sweeteners. For more in-depth discussion, one should refer to intermolecular weak interactions and side groove sections in aspartyl sweeteners paper ${ }^{2}$. Another characteristics for bitter taste is bitterness intensity, which is due to the extent of helix oscillation.

Similar to sweet taste receptor, multiple bitter receptors or multiple binding sites on a single receptor are well expected. It is because the recognition process only involves a very small helix piece, which is a small fragment of a whole receptor. It has been known that different molecules could bind to different spots of sweet receptor (T1R2/T1R3), although it seems not clearly stated in bitter receptors. In bitter receptor case, there are 25 bitter receptors. Multiple binding sites in one receptor are very likely. The finding of multiple bitter receptors will be another supporting evidence for this theory.

As the bitter receptor's torsion-spring-like oscillation makes the grooves get narrower. It makes the receptor more sensitive to bitter molecules' size, shape, and other properties, and may need different receptors to sense different bitter molecules. 


\section{ACKNOWLEDGEMENTS}

I am grateful to Dr. Fengxia Deng for her decades-long encouragement and support for completing this research. I would like to thank Mr. Charlie He for his help in organizing data. I would also like to thank the late Professor Guangzhi Zeng (Kuangchi Tseng) for leading me into this fascinating area.

\section{CONFLICT OF INTEREST}

The author declares no conflicts of interest with the contents of this article.

\section{FUNDING}

There is no funding for this research.

\section{REFERENCES}

1 He, Huazhong: Ultimate Molecular Theory of Sweet Taste. Research Square. Preprint. doi:10.21203/rs.3.rs-141448/v1 (2021)

2 He, Huazhong: Deciphering Aspartyl Peptide Sweeteners Using the Ultimate Molecular Theory of Sweet Taste. ChemRxiv. Preprint. https://doi.org/10.26434/chemrxiv.13488177.v1 (2021)

3 Zeng, G. \& Wei, S. Molecular recognition of Gustation (Science Press (China) 1984).

4 Moncrieff, R. W. The Chemical Senses. (CRC Press, 1967).

5 Shallenberger, R. S., Acree, T. E. \& Lee, C. Y. Sweet taste of D and Lsugars and amino-acids and the steric nature of their chemo-receptor site. Nature 221, 555-556 (1969).

6 Kubota, T. \& Kubo, I. Bitterness and Chemical Structure. Nature 223, 97, doi:10.1038/223097a0 (1969).

7 Lehmann, P. A. The correlation of sweetness and bitterness of enantiomeric aminoacids. Life Sci 22, 1631-1635 (1978).

8 Kier, L. B. A molecular theory of sweet taste. J Pharm Sci 61, 1394-1397 (1972).

$9 \quad$ Belitz, H. D. \& Wieser, H. Bitter compounds: Occurrence and structure - activity relationships. Food Reviews International 1, 271-354, doi:10.1080/87559128509540773 (1985).

10 Adler, E. et al. A Novel Family of Mammalian Taste Receptors. Cell 100, 693-702, doi:https://doi.org/10.1016/S0092-8674(00)80705-9 (2000).

11 Chandrashekar, J. et al. T2Rs function as bitter taste receptors. Cell 100, 703-711 (2000).

12 Matsunami, H., Montmayeur, J. P. \& Buck, L. B. A family of candidate taste receptors in human and mouse. Nature 404, 601-604, doi:10.1038/35007072 (2000).

13 Nelson, G. et al. Mammalian Sweet Taste Receptors. Cell 106, 381-390, doi:10.1016/S0092-8674(01)00451-2 (2001). 
14 Bachmanov, A. A. et al. Positional cloning of the mouse saccharin preference (Sac) locus. Chem Senses 26, 925-933 (2001).

15 Kitagawa, M., Kusakabe, Y., Miura, H., Ninomiya, Y. \& Hino, A. Molecular genetic identification of a candidate receptor gene for sweet taste. Biochem Biophys Res Commun 283, 236-242, doi:10.1006/bbrc.2001.4760 (2001).

16 Li, X., Inoue, M., Reed, D. R., Huque, T., Puchalski, R. B., Tordoff, M. G., Ninomiya, Y., Beauchamp, G. K., Bachmanov, A. A. High-resolution genetic mapping of the saccharin preference locus (Sac) and the putative sweet taste receptor (T1R1) gene (Gpr70) to mouse distal Chromosome 4. Mamm Genome 12, 13-16 (2001).

17 Max, M. et al. Tas1r3, encoding a new candidate taste receptor, is allelic to the sweet responsiveness locus Sac. Nat Genet 28, 58-63, doi:10.1038/88270 (2001).

18 Montmayeur, J. P., Liberles, S. D., Matsunami, H. \& Buck, L. B. A candidate taste receptor gene near a sweet taste locus. Nat Neurosci 4 , 492-498, doi:10.1038/87440 (2001).

19 Sainz, E., Korley, J. N., Battey, J. F. \& Sullivan, S. L. Identification of a novel member of the T1R family of putative taste receptors. $J$ Neurochem 77, 896-903 (2001).

20 Pettersen, E. F., Goddard, Thomas D., Huang, Conrad C., Couch, Gregory S., Greenblatt, Daniel M., Meng, Elaine C., Ferrin, Thomas E. UCSF Chimera-A visualization system for exploratory research and analysis. Journal of Computational Chemistry 25, 1605-1612, doi:10.1002/jcc.20084 (2004).

21 Trott, O. \& Olson, A. J. AutoDock Vina: Improving the speed and accuracy of docking with a new scoring function, efficient optimization, and multithreading. Journal of Computational Chemistry 31, 455-461, doi:10.1002/jcc.21334 (2010).

22 Sanner, M. F. Python: a programming language for software integration and development. J Mol Graph Model 17, 57-61 (1999).

23 Arctander, S. Perfume and flavor chemicals:(aroma chemicals). Vol. 2 (Allured Publishing Corporation 4-methyl-valeric acid: unleasant sour and penetrating odor. Less fatty-sweat-like than caproic acid, more pungent., 1969).

24 National Center for Biotechnology Information. PubChem Compound Database; $C I D=107$, https://pubchem.ncbi.nlm.nih.gov/compound/107 (accessed July 6, 2018).

25 Hunter, R. \& Scherren, H. Phloretic acid in The encyclopaedic dictionary: a new and original work of reference to all the words in the English language. P490 (1902).

26 Wieser, H. \& Belitz, H. D. [Relations between structure and bitter taste of amino acids and peptides. I. Amino acids and related compounds]. $Z$ Lebensm Unters Forsch 159, 65-72 (1975).

27 Wieser, H., Stempfl, W., Grosch, W. \& Belitz, H.-D. Untersuchungen über den Bittergeschmack von Emulsionen höherer Fettsäuren. Zeitschrift fur 
Lebensmittel-Untersuchung und -Forschung 179, 447-449, doi:10.1007/bf01043422 (1984).

28 Lainer, J. et al. Characterization of Bitter-Tasting Oxylipins in Poppy Seeds (Papaver somniferum L.). Journal of agricultural and food chemistry, doi:10.1021/acs.jafc.9b06655 (2019).

29 Khan, S. Overview of strychnine poisoning. The Merck Veterinary Manual, 10th ed.; Kahn, CM, Line, S., Eds, 2744-2746 (2010).

30 Oxford, A. E., Perkin, W. H. \& Robinson, R. CCCXX.-Strychnine and brucine. Part VI. The catalytic hydrogenation of strychnine and some derivatives. Journal of the Chemical Society (Resumed), 2389-2410, doi:10.1039/JR9270002389 (1927).

31 Warnat, K. Über drei neue Strychnos - alkaloide. Helvetica Chimica Acta 14, 997-1007 (1931).

32 Mostad, A. Crystal and molecular structure of pseudostrychnine. Acta Chemica Scandinavica 42, 397 (1988).

33 Sandberg, F. \& Kristianson, K. A comparative study of the convulsant effects of strychnos alkaloids. Acta Pharm Suec 7, 329-336 (1970).

34 Tsang, J. W., Schmied, B., Nyfeler, R. \& Goodman, M. Peptide sweeteners. 6 . Structural studies on the C-terminal amino acid of Laspartyl dipeptide sweeteners. J Med Chem 27, 1663-1668 (1984).

35 Douglas, A. J. \& Goodman, M. in Sweeteners Vol. 450 ACS Symposium Series Ch. 10, 128-142 (American Chemical Society, 1991).

36 Rodriguez, M., Bland, J. M., Tsang, J. W. \& Goodman, M. Peptide sweeteners. 8. Synthesis and structure-taste relationship studies of Laspartyl-D-alanyl tripeptides. J Med Chem 28, 1527-1529 (1985).

37 Treleano, R., Belitz, H.-D., Jugel, H. \& Wieser, H. Beziehungen zwischen Struktur und Geschmack bei Aminosäuren mit cyclischen Seitenketten. Zeitschrift für Lebensmittel-Untersuchung und Forschung 167, 320-323, doi:10.1007/bf01415925 (1978).

38 Boudreau, J. C. Food Taste Chemistry. Vol. 115 (AMERICAN CHEMICAL SOCIETY, 1979).

39 Saroli, A. Structure-activity relationship of a bitter compound: denatonium chloride. Naturwissenschaften 71, 428-429, doi:10.1007/BF00365895 (1984).

40 Saroli, A. Interaction of denatonium chloride with the bitter taste receptor. Zeitschrift für Lebensmittel-Untersuchung und Forschung 180, 227-229, doi:10.1007/BF01027270 (1985).

41 Saroli, A. Structure-activity relationship of bitter compounds related to denatonium chloride and dipeptide methyl esters. Zeitschrift für Lebensmittel-Untersuchung und Forschung 182, 118-120, doi:10.1007/BF01454242 (1986).

42 Saroli, A. Structure - activity relationship of bitter dipeptide esters. Zeitschrift für Lebensmittel-Untersuchung und Forschung 184, 122-124, doi:10.1007/bf01042085 (1987).

43 Commission, U. C. P. S. (1992). 
44 Amino, Y., Mori, K., Tomiyama, Y., Sakata, H. \& Fujieda, T. in Sweetness and Sweeteners Vol. 979 ACS Symposium Series Ch. 30, 463-480 (American Chemical Society, 2008).

45 Zeng, G., Chen, J., He, H., Wang, Z. \& Yan, J. In the pursuit of a better sweetener. Journal of agricultural and food chemistry 39, 782-785 (1991).

46 Pangborn, R. M., Lewis, M. J. \& Yamashita, J. F. COMPARISON OF TIME-INTENSITY WITH CATEGORY SCALING OF BITTERNESS OF ISO- $\alpha$-ACIDS IN MODEL SYSTEMS AND IN BEER*. Journal of the Institute of Brewing 89, 349-355, doi:10.1002/j.2050-0416.1983.tb04201.x (1983).

47 Leach, E. J. \& Noble, A. C. Comparison of bitterness of caffeine and quinine by a time - intensity procedure. Chemical senses 11, 339-345, doi:10.1093/chemse/11.3.339 (1986).

48 Melis, M. \& Tomassini Barbarossa, I. Taste Perception of Sweet, Sour, Salty, Bitter, and Umami and Changes Due to I-Arginine Supplementation, as a Function of Genetic Ability to Taste 6-n-Propylthiouracil. Nutrients $\mathbf{9}$, doi:10.3390/nu9060541 (2017).

49 Khataan, N. H., Stewart, L., Brenner, D. M., Cornelis, M. C. \& El-Sohemy, A. TAS2R38 genotypes and phenylthiocarbamide bitter taste perception in a population of young adults. $J$ Nutrigenet Nutrigenomics 2, 251-256, doi:10.1159/000297217 (2009).

50 Pronin, A. N. et al. Specific alleles of bitter receptor genes influence human sensitivity to the bitterness of aloin and saccharin. Curr Biol 17, 1403-1408, doi:10.1016/j.cub.2007.07.046 (2007).

51 Bufe, B. et al. The Molecular Basis of Individual Differences in Phenylthiocarbamide and Propylthiouracil Bitterness Perception. Current Biology 15, 322-327, doi:https://doi.org/10.1016/j.cub.2005.01.047 (2005).

52 Duffy, V. B. et al. Bitter receptor gene (TAS2R38), 6-n-propylthiouracil (PROP) bitterness and alcohol intake. Alcohol Clin Exp Res 28, 16291637 (2004).

53 Pronin, A. N., Tang, H., Connor, J. \& Keung, W. Identification of ligands for two human bitter T2R receptors. Chem Senses 29, 583-593, doi:10.1093/chemse/bjh064 (2004).

54 Sainz, E. et al. Functional characterization of human bitter taste receptors. Biochem J 403, 537-543, doi:10.1042/BJ20061744 (2007).

55 Fox, A. L. The Relationship between Chemical Constitution and Taste. Proceedings of the National Academy of Sciences 18, 115-120, doi:10.1073/pnas.18.1.115 (1932). 